\title{
The Economic Pressure and Coping Strategy of the Family of Cash Conditional Transfer Recipients
}

\author{
Megawati Simanjuntak* \\ Department of Family and Consumer Sciences, \\ Faculty of Human Ecology, \\ Bogor Agricultural University \\ *Corresponding author: mega.juntakipb@gmail.com
}

\begin{abstract}
Cash Conditional Transfer (CCT) or Program Keluarga Harapan (PKH) is one of the attempts of Indonesian government to alleviate poverty. This study conducted in eight villages in Dramaga District, Bogor Regency for six months. This study aimed to analyze the difference of economic pressure and families coping strategies of economic functions between pre and post the family got CCT' $s$ funds and to analyze the relationship of socioeconomic and demographic characteristics, economic pressure and coping strategies of economic functions. By using systematic random sampling, this study produced 150 samples. Family size, amount of debt, the ratio of debt and assets, and economic pressure significantly and positively correlated with the total coping strategies both in pre and post-CCT. On the other hand, the total coping strategies both in the pre and post-CCT also significantly and negatively correlated with the level education of wives. In addition, the husbands and wives age significantly and positively related to the coping strategies during post $\mathrm{CCT}$, while the total family income correlated significantly and negatively.
\end{abstract}

Keywords: economic pressure, coping strategy, Cash Conditional Transfer

\begin{abstract}
Abstrak. Program Keluarga Harapan (PKH) merupakan salah satu upaya pemerintah Indonesia dalam mengurangi kemiskinan. Penelitian ini dilakukan di delapan desa di Kecamatan Dramaga, Kabupaten Bogor selama enam bulan. Penelitian ini bertujuan untuk menganalisis perbedaan tekanan ekonomi dan stategi koping fungsi ekonomi antara sebelum dan setelah mendapat dana PKH serta untuk menganalisis hubungan karakteristik sosial ekonomi dan demografi, tekanan ekonomi dan strategi koping fungsi ekonomi. Dengan menggunakan teknik sampling acak sistematis, penelitian ini melibatkan 150 sampel. Penelitian ini menunjukkan bahwa besar keluarga, hutang, rasio hutang dan aset, dan tekanan ekonomi secara signifikan berkorelasi dengan strategi koping, baik sebelum maupun sesudah menerima dana PKH. Di sisi lain, strategi koping, baik sebelum maupun sesudah menerima dana $\mathrm{PKH}$, berkorelasi negatif signifikan dengan tingkat pendidikan istri. Sementara itu, setelah menerima dana PKH, usia suami dan usia istri berkorelasi positif signifikan dengan strategi koping, sedangkan pendapatan keluarga berkorelasi negatif dengan strategi koping.
\end{abstract}

Kata kunci: Program Keluarga Harapan, strategi koping, tekanan ekonomi 


\section{Introduction}

During 2014 and 2015, the number of the poor in Indonesia has increased from 27.73 million to 28.51 million (Statistics Indonesia, 2016). The government of Indonesia has attempted various efforts to reduce poverty. One of them is Conditional Cash Transfer (CCT), which is specifically well known in Indonesia as Program Keluarga Harapan (PKH). The main purpose of CCT is to reduce poverty and improve the quality of human resources, especially in the poor communities. It also aims to accelerating the achievement of Millennium Development Goals (MDGs) by the year of 2015.

Based on Fiszbein and Schady (2009) exploration, Conditional Cash Transfers (CCTs) in many countries are programs that transfer cash, generally to poor households, in the condition that those households make prespecified investments in the human capital of their children. By and large, CCTs have increased consumption levels among the poor. Thus, they have resulted in sometimes substantial reductions in poverty among beneficiaries-especially when the transfer has been generous, well targeted, and structured in a way that does not discourage recipients from taking other actions to escape poverty. The CCTs have been widely implemented since it gives positive effects on household consumption and on poverty (as measured by the headcount index, the poverty gap, an the squared poverty gap).

Research on the evaluation of poverty reduction programs has been more focused on the study of effectiveness, the supply program, or the study of program implementation which has been frequently done by the World Bank and other research institutions. On the other hand, research on the family- recipients of poverty reduction programs in Indonesia- has been rarely conducted, especially on such aspects as the coping mechanism which is used when facing the family' $\mathrm{s}$ economic pressures. However, among these studies, there is no comparing condition of the family before and after receiving the program. Therefore, this study focuses on examining how much the change felt by beneficiary families before and after the program. This study also use appropriate and newer methods in order to capture the changes precisely.

Economic pressure, conceptualized as the family's perceived financial inability to meet family necessities, is distinguished from economic conditions that include more structural indicators of poverty (Conger et al., 2002). A study by Robila (2006) concluded that higher community poverty and exclusion is also associated with higher economic pressure. In this study, economic pressure is financial difficulties experienced by family during pre-period and post-period of receiving CCT funds.

Coping strategies are someone attempts to control, reduce, and tolerate demands or problems (Hastuti and Milyawati, 2009). Coping strategy in the state of economic function is the effort made by family to manage the difficulties on family resources that most possibly would allow fulfilment of material needs more adequately by implementing two ways, namely searching for additional revenue and performing savings during both pre-period and post-period of receiving the CCT funds.

With those considerations, this study aimed to analyze the difference of economic pressure and economic functions, families coping strategies between pre and post receiving CCT funds, as well as to analyze the relationship between socioeconomic and demographic characteristics, economic pressure and coping strategies of economic functions. The novelty of the study is the design and the methods used. This study 
applied a combination of cross-sectional and retrospective designs that it was essential to analyze the differences between the pre and post receiving CCT funds.

\section{Method}

\section{Participants}

The study was conducted in six months at eight villages (Purwasari, Petir, Sukadamai, Sukawening, Neglasari, Sinarsari, Ciherang, and Dramaga) in the Dramaga District, Bogor Regency. The population of this study was the families who receiving CCT funding. The sampling method was using systematic random sampling which produced 150 samples with housewives as the respondents.

\section{Measures}

The primary data included demographic and socioeconomic characteristics (family size, age, education level, job, and income), economic pressures, and family coping strategies in the state of economic function. The secondary data were obtained from Statisctics Indonesia, village office, local sub-district office, and CCT officers of Dramaga District. Data were collected by interview using questionnaires.

Economic pressure is a financial difficulty experienced before and after family received CCT funds. The questionnaire of family economic pressure consisted of 10 items of questions using a scale of $1=$ Depressed, $2=$ Quite Depressed, and $3=$ Not Depressed, with the reliability value of 0.926. The higher the score, the higher the economic pressure felt by families. The obtained score was divided into three categories: not depressed (score <60), quite depressed (score 60-80), and distressed (score> 80).

Coping strategies in the study referred to the effort made by the family to organize the difficulties of family resource that will allow the fulfillment of material needs by applying two ways, namely income generating and cutting back expenses both in pre and post-CCT funds. The measurement of coping strategies included 41 items that were divided into two dimensions, namely saving strategies and seek additional revenue. The items of number of savings strategy were rated on a scale of $1=$ Never, 2 $=$ Sometimes, and $3=$ Often, and the reliability value of 0.760 . Composite scores were transformed into a scale of 0 to 100 , where the higher the score, the more coping strategies undertaken by families. The categorization score was low (score <60), moderate (score of 60-80), and high (score> 80).

\section{Analysis}

The data processing was done in two ways, namely descriptive statistics and inferential statistics. The statistical analysis used is Paired Samples T-test and Spearman/Pearson correlation.

\section{Result}

\section{Demographic and Socioeconomic Characteristics}

Demographic and socioeconomic characteristics of the families of this study 
were described as follows: the largest percentage of family size ranged from 5 to 6 people structured as nuclear family, and the husbands and wives aged between 30 and 49 years old. This result is in line with a study by Amendah et al. (2014) that the main income earner in the household aged about 34 years old. The education level of the husbands and wives were up to primary school. Husbands worked as laborers, while most of the wives did not work. The total of family income increased significantly 1.3 times during the pre period of receiving CCT fund. The average of total family income per month per capita was Rp89.594,01 during the pre period of receiving CCT fund and Rp118.044,96 during the post period. Statistical analysis of differential paired test between the pre period and the post period of receiving CCT fund showed that there was a significant difference $(\mathrm{p}=0.000)$ between the two states. The percentage of poor families in the pre period of receiving CCT fund was 82.7 percent, while in the post period the percentage increased slightly to 83.3 percent.

\section{Economic Pressures}

The economic pressure during the pre period of receiving CCT fund felt by half to three-fifths of the families categorized under the pressed turned out to be two-fifths in such aspects as having the sufficient finance for the family $(67.3 \%$ pre period of receiving CCT fund; 17.3 percent post period of receiving CCT fund), sending their school-age children $(61.3 \%$ pre period of receiving CCT fund; 8.7 percent post period of receiving CCT fund), paying for children school needs $(62.7 \%$ pre period of receiving CCT fund; 7.3 percent post period of receiving CCT fund), and buying food including daily snacks $(52.0 \%$ pre period of receiving CCT fund; 20.7 percent post period of receiving CCT fund). Those changes were favorably the reason why the families that were categorized under the economically pressed did not become more depressed.

Table 1 Distribution and different test of family economic pressures items

\begin{tabular}{|c|c|c|c|c|c|}
\hline \multirow[b]{2}{*}{ No. } & \multirow[b]{2}{*}{ Items of economic pressures } & \multicolumn{3}{|c|}{ Means (score 1-3) } & \multirow[b]{2}{*}{$\begin{array}{l}\text { Independent } \\
\text { t-test (Sig) }\end{array}$} \\
\hline & & $\begin{array}{l}\text { Pre } \\
\text { CCT }\end{array}$ & $\begin{array}{l}\text { Post } \\
\text { CCT }\end{array}$ & $\begin{array}{c}\text { Delta } \\
\text { (Post-Pre) }\end{array}$ & \\
\hline 1. & The adequacy of family finances & 2.47 & 1.75 & -0.72 & $0.000^{* *}$ \\
\hline 2. & Sending their school-age children & 2.31 & 1.41 & -0.90 & $0.000^{* *}$ \\
\hline 3. & Paying for school children & 2.35 & 1.39 & -0.96 & $0.000^{* *}$ \\
\hline 4. & Buying clothes family members & 1.95 & 1.55 & -0.40 & $0.000^{* *}$ \\
\hline 5. & Meeting the needs of material (furniture) & 1.75 & 1.57 & -0.18 & $0.000^{* *}$ \\
\hline 6. & Meet desired goods for family & 1.87 & 1.64 & -0.23 & $0.000^{* *}$ \\
\hline 7. & $\begin{array}{l}\text { Buying food needs of the family. including daily } \\
\text { snacks }\end{array}$ & 2.25 & 1.81 & -0.44 & $0.000^{* *}$ \\
\hline 8. & Paying for electricity per month & 2.00 & 1.79 & -0.21 & $0.000^{* *}$ \\
\hline 9. & Buying non-food items (soap. health purposes) & 1.86 & 1.59 & -0.27 & $0.000^{* *}$ \\
\hline 10. & Paying medical bills & 1.83 & 1.63 & -0.20 & $0.000^{* *}$ \\
\hline \multicolumn{2}{|c|}{ Total (item 1-10) } & 2.06 & 1.61 & -0.45 & $0.000^{* *}$ \\
\hline
\end{tabular}

The score of every item of economic pressure was presented in Table 1 . The scale was scored into 3=depressed, 2=quite depressed, and 1=not depressed. Two items as sending their school-age children and paying for school had the highest gap between pre and post CCT respectively 0.90 and 0.96. Otherwise, the lowest gap between the two period was meeting the needs of material (furniture) as the gap was 0.18 .

The derived economic pressure composite score means that the higher the score, 
the higher the economic pressures experienced by families. Based on the categorization of economic pressure, more than half $(52.7 \%)$ of the families in the pre period of receiving CCT fund was classified as not depressed, which in turn improved, which then made most of the families $(81.3 \%)$ to be in not depressed category. The average economic pressure score also decreased from 53.27 in the pre period of receiving CCT fund to 30.67 in the post-period of receiving CCT fund, in which this difference was statistically significant in the value of $p=0.000$. These data suggest that the grant of CCT funds have implications for the drop of economic pressure experienced by the families. This was understandable in the case that the CCT funds can most likely reduce the economic burden felt by families. This indication was also more noticeable by the drop of percentage amount of families that were economically distressed from 26.7 percent in the pre period of receiving CCT fund to 4.7 percent in the post-period of receiving CCT fund (Table 2).

Table 2 Distribution and pairs t-test on family economic pressure before and after CCT $(\mathrm{n}=150)$

\begin{tabular}{lcc}
\hline Category of economic pressure & Pre CCT & Post CCT \\
\hline Not pressed (score $<60)$ & 52.7 & 81.3 \\
Pressed Enough (score 60-80) & 20.7 & 14.0 \\
Pressed (score $>$ 80) & 26.6 & 4.7 \\
Pairs t-test (sig) & & $0.000^{* *}$ \\
\hline
\end{tabular}

Note. $(* *)$ significant at $\mathrm{p}$-value $<0.01$

\section{Coping Strategy}

The coping mechanism aims to mitigate the impact of economic pressures by leveraging resources, both positively and negatively. The coping mechanisms can be both positive in reducing family' s spending or increasing family productivity, and negative in borrowing some money (Voydanoff and Donnelly, 1988). Puspitawati (2012) suggests two types of family economic coping strategies, namely the addition of revenue (generating additional income) and spending cuts (cutting back expenses). In this study, both coping strategies in response to the financial problems were implemented to seek additional income and savings.

Table 3 Means and pairs t-test of coping strategies in economic function

\begin{tabular}{lcccc}
\hline Strategies & Pre CCT & Post CCT & Delta (Post-Pre) & Pairs t-test (Sig) \\
\hline Cutting Back Expenses & & & & \\
Food & 1.93 & 1.85 & -0.08 & $0.000^{* *}$ \\
Health & 1.99 & 1.94 & -0.05 & $0.001^{* *}$ \\
Eduction & 1.40 & 1.34 & -0.06 & $0.000^{* *}$ \\
Other Expenses & 2.70 & 2.65 & -0.05 & 0.057 \\
Income Generating & & & & \\
Food & 2.06 & 2.03 & -0.03 & 0.309 \\
Health & 1.69 & 1.70 & 0.01 & 0.435 \\
Eduction & 1.18 & 1.17 & -0.01 & 0.539 \\
Other Expenses & 1.20 & 1.19 & -0.01 & 0.151 \\
\hline
\end{tabular}

Note. $(*)$ significant at $\mathrm{p}<0.01$

Based on the delta of score between before and after CCT decreased coping efforts undertaken by families. In particular, coping strategy on cutting back expenses is a noticeable difference in the dimensions of food, health, and education ( $p<0.01)$. This indicates that the presence of CCT funds enables the family to keep thw ampunt 
of its spending. This result is in line with the previous study concluding that the more prosperous families will be less likely to perform coping strategies (Rosidah et al., 2012). Meanwhile, on income generating strategy, there is no significant difference in all dimensions, although there were a downward trend in coping efforts in all dimensions with a very small delta. That is, families did coping to increase revenue with no changes between the pre and post period of receiving the CCT funds (Table 3).

If it were viewed based on two-dimensional coping strategies that families had been done, which were reducing family expenditure and increasing family income, then the most widely used coping strategies was reducing family expenditure and there was a significant difference $(\mathrm{p}=0.000)$ in reducing expenditure between the pre and post-of receiving CCT funds. On the other hand, the score of coping strategies in increasing family income did not show any significant differences $(\mathrm{p}=0.151)$ (Table 4).

Table 4 The distribution and pairs t-test of coping strategies on families economic function for pre and after CCT funds

\section{Correlation between Variables}

The result of correlation analysis indicated that several variables were significantly correlated with the total coping strategies both in the pre period of receiving CCT funds and post period of receiving CCT funds. Those are the family size $(\mathrm{rs}=0.263, \mathrm{p}<0.01)$, amount of debt $(\mathrm{rs}=0.256, \mathrm{p}<0.01)$, the ratio of debt and assets ( $r s=0.280, p<0.01)$, and economic pressure $(r s=0.489, p<0.01)$; on the other hand, it also had a significantly negative correlation with the level education of wives ( $r s=-0.172$, $\mathrm{p}<0.05)$. Some positive variables related significantly to the coping strategies during post-period of receiving CCT funds were the family size ( $\mathrm{rs}=0.284, \mathrm{p}<0.01$ ), age of husbands ( $\mathrm{rs}=0.214, \mathrm{p}<0.05$ ), age of wives ( $\mathrm{rs}=0.197, \mathrm{p}<0.05)$, amount of debt $(\mathrm{rs}=0.296, \mathrm{p}<0.01)$, the ratio of debt and assets $(\mathrm{rs}=0.277, \mathrm{p}<0.01)$, and economic pressure ( $\mathrm{rs}=0.439, \mathrm{p}<0.01)$; on the other hand, it also had a significantly negative correlation with the education level of wives $(\mathrm{rs}=-0.261, \mathrm{p}<0.01)$ and total of family income ( $\mathrm{rs}=-0.214, \mathrm{p}<0.01)$ (Table 5).

The result of Spearman correlation analysis showed a significantly positive relationship between the strategy on reducing expenditure and the strategy on increasing income both for pre period of receiving CCT funds ( $\mathrm{rs}=0.212, \mathrm{p}<0.01$ ) and postperiod of receiving CCT funds ( $r s=0.200, \mathrm{p}<0.05$ ). It implies that the better the family 
can reduce its expenditure, the better the family can increase its income. Meanwhile, another preferable coping strategy which is tended to be applied by households at various levels of food security was to change the eating habits $(51.5 \%)$.

Table 5 Coefficient correlation betweeen variables

\begin{tabular}{lcc}
\hline \multirow{2}{*}{ Variables } & \multicolumn{2}{c}{ Coping Strategy } \\
\cline { 2 - 3 } Family Size & Pre CCT & Post CCT \\
Husband's Age & $0.263^{* *}$ & $0.284^{* *}$ \\
Wives' Age & 0.160 & $0.214^{*}$ \\
Husband's Education & 0.144 & $0.197^{*}$ \\
Wives' Education & -0.058 & -0.053 \\
Total of Family Income & $-0.172^{*}$ & $-0.261^{* *}$ \\
Amount of Debt & -0.155 & $-0.214^{* *}$ \\
The Ratio of Debt \& Asset & $0.256^{* *}$ & $0.296^{* *}$ \\
Economic pressures & $0.280^{* *}$ & $0.277^{* *}$ \\
\hline
\end{tabular}

Note. $\left({ }^{*}\right)$ significant at $\mathrm{p}<0.05 ;(* *)$ significant at $\mathrm{p}<0.01$

\section{Discussion}

There was a significant increament in the total income when the family received the CCT fund. With the additional income received from CCT fund, the average income per capita was 1.3 times higher than the pre period of receiving CCT fund. The CCT program could probably increase the income of poor families in a short time and enhance human capabilities in the medium and long term (Son, 2008). Based on indepth-interview, some respondent stated:

The money from CCT usually runs out in just one to two days. I am really grateful to have earned money from CCT. But, I think there is no changes after getting CCT, especially in the economic conditions of my family.

CCT's money usually runs out in just half a month, but it's still enough to meet the family need.

CCT's money usually runs out more than one week. I felt grateful to earn money from CCT, but no changes occur after getting CCT.

\section{CCT's funds was exhausted in just two days.}

There was an increasing of poor families after they received CCT fund as 0.6 percent. Prior to the disbursement of CCT, many families borrowed money since they feel would soon get CCT funds, so after they received the money, they have to pay the loan. Their negative behavioral change (borrowing money) may generate poverty and/or cause its persistence (Gu'nther and Harttgen, 2009). The amount of the money they borrowed was greater than the funds that would be disbursed. This causes the receiver instead of increasing family welfare but poorer than before. One of respondents stated:

The family debt is increased after receving CCT because the expense is getting more. The money is used for the needs of school children, buying 


\section{rice and tobacco for my husband.}

The findings of this study were yet far from the result of a similar program in Colombia, which could reduce the poverty rate to six percent. The impact of CCT on poverty varied among its programs, with Progresa showed the most significant results. Bourguignon et al. (2002) found a very little impact on poverty and inequality for the Bolsa Escola as a small number of transfers. Zepeda (2006) also concluded that CCT programs did make a huge difference in poor household' $s$ income, but yet did not reduce poverty significantly. Based on these results, we need a rules regarding the use of cash transfer family received in order to be used properly. Family financial management assistance ia also needed during this program in order to make them capable to manage their finance during and after completion of the program.

The increasing of family income results in the declining economic pressure, and eventually the wives will feel better off or satisfied with the family' $s$ life. Regarding this case, CCT program can be called as an incentive-based welfare program. This programs were acknowledged for their run in helping the poor families to overcome poverty by reducing the major barriers faced by the poor.

If it were viewed based on two-dimensional coping strategies that families had been done, which were reducing family' $s$ expenditure and increasing family' $s$ income, then the most widely used coping strategy was reducing family expenditure and there was a significant difference $(\mathrm{p}=0.000)$ in reducing expenditure between the preperiod and post-period of receiving CCT funds. On the other hand, the score of coping strategies in increasing family income did not show any significant differences $(\mathrm{p}=0.151)$.

The indications of these data were that the family tended not to make effort on striving their revenue (generating income), which was more productive, but on saving or cutting their spending, either of which was identically more passive. The difficulty on finding a job or lack of resource was favorably the reason why family did not intend to find an additional income.

In terms of coping strategies that increase family income, family tended to choose coping strategies by saving money on food, health, education, and other expenses. This passive coping strategy was commonly preferred due to the limited resources owned by the family to conduct an active one, such as due to the unavailability of land, low education level, no job, no assets or no place to borrow money. This goes along with the research of Kusumo (2008) which stated that in the face of economic difficulties, farmer families likely prefer to apply the saving strategies more frequently rather than applying the resource replenishment strategies or social strategy.

The result of coping score categorization performed by families indicated that more than a half of samples were classified as moderate either in the pre-period or postperiod of receiving CCT funds. Statistically, there was a significant difference of coping strategy, which means that the efforts of coping mechanisms are decreased significantly when families receive CCT funds.

The family size was positively and significantly associated with the total coping strategies both pre and post period of receiving CCT funds. This indicates that the more members of the family, the more optimal effort needed to overcome the problem itself. A study by Amendah et al. (2014) concluded that the large number of children under 15 years increased the probability of using a coping strategy.

The total debt, debt ratio, and asset were positively and significantly associated 
with total coping strategy, indicating that the more debt a family had, the more effort they put intensively to get rid of it either through savings or increasing their income. On the other hand, the length of wives' education was negatively and significantly related to total coping strategies. This means that the higher the wives's education level, the fewer coping strategies required. The higher the wives' education level, the better economy status the family would likely pursue; thus, the family does not face the problem of finding additional savings or income.

The age of husbands and wives were positively and significantly associated with the total coping strategies during the pre-period of achieving CCT fund, indicating that the older the age of husbands and wives, the more coping strategies to be applied. The enormous life experiences of older ones will engage opportunities or choices to make coping strategies in addressing the increasing problems. The more coping strategies applied, the more CCT fund allocated for non-educational activities, meaning that those various coping efforts most likely increase the fund allocation for non-educational matter. Expenditure on food and non food and also the total family revenue were negatively related to the total coping strategies. This is understandable in a matter that the coping efforts which were mostly done by the sample were savings. No doubt that this has implications on the decreasing of family expenditure. However, since the total revenue was negatively related to family coping strategies, it can be interpreted inversely that the more income the family receive (to achieve a better economy), the fewer coping strategies particularly on savings a family needs to deal with. This was supported by the fact that savings coping strategy was negatively and significantly correlated with the total family income.

The limitation of this study are the using of recall method in collecting data may cause error answers since it relies only on memories. Also, the interview for pre and post period of CCT was conducted in the same time, it could cause misperception regarding the time frame of the questions.

\section{Conclusion and Recommendation}

\section{Conclusion}

The study shows that the CCT funding have implications toward the decrease of economic pressure experienced by family. Family size, amount of debt, the ratio of debt and assets, and economic pressure are significantly and positively correlated with the total coping strategies both in pre and post-CCT. On the other hand, the total coping strategies both in the pre and post-CCT are also significantly and negatively correlated with the level education of wives. In addition, the age of husbands and wives are significantly and positively related to the coping strategies during post CCT, while the total family income is significantly and negatively correlated.

\section{Recommendation}

The result of the study showed that the coping mechanisms which are applied declined during the post CCT. This case reinforces CCT as an incentive-based welfare program. Moreover, CCT program has certainly proved to help the poor communities to overcome poverty by reducing the main barriers. Besides the efforts to carry out CCT program, it is important for the government to provide facilities and infrastructures which support the economic empowerment of families to be more active and 
independent in optimizing its resources and not merely just in the form of receiving incentives. For further research, it is recommended to conduct a study on others variables that influence coping strategies and compare coping strategies between the poor and non-poor families.

\section{References}

Amendah, D. D., Buigut, S., \& Mohamed, S. (2014). Coping strategies among urban poor: Evidence from Nairobi, Kenya. PLoS ONE, 9(1), 1-8. doi: 10.1371/journal.pone.0083428.

Bourguignon, F., Ferreira, F., \& Leite, P. (2002). Ex-ante evaluation of conditional cash transfer programs: The case of Bolsa Escola (Policy Research Working Paper No. 2916, World Bank, Washington, DC. doi: 10.1596/1813-9450-2916.

Conger, R. D., Wallace, L. E., Sun, Y., Simons, R. L., McLoyd, V. C., \& Brody, G. H. (2002). Economic pressure in African American families: A replication and extension of the family stress model. Developmental Psychology, 38, 179-193.

Fiszbein, A. \& Schady, N. (2009). Conditional Cash Transfer: Reducing Present and Future Poverty. Washington DC: The International Bank for Reconstruction and Development/The World Bank.

Gu'nther, I., \& Harttgen, K. (2009). Estimating Households Vulnerability to Idiosyncratic and Covariate Shocks: A Novel Method Applied in Madagascar. World Development, 37(7), 1222-1234. doi: 10.1016/j.worlddev.2008.11.006.

Hastuti, D., \& Milyawati, L. (2009). Dukungan keluarga, pengetahuan, dan persepsi ibu serta hubungannya dengan strategi koping ibu pada anak dengan gangguan Autism Spectrum Disorder (ASD) [Family Support, mother's knowledge and perception of asd, and its correlation with coping strategy of mothers with Autism Spectrum Disorder (ASD) children]. Jurnal Ilmu Keluarga dan Konsumen, 2(2), 137-142. Retrieved from http://journal.ipb.ac.id/index.php/jikk/article/view/5170/3566.

Kusumo, R. A. B., Sunarti, E., \& Pranadji, D. K. (2008). Analisis Peran Gender serta Hubungannya dengan Kesejahteraan Keluarga Petani Padi dan Hortikultura di Daerah Pinggiran Perkotaan [The role of gender in coping strategies and family resource management and its relationship with the family welfare of rice and horticulture farmers in the urban fringe]. Media Gizi dan Keluarga, 32(2), 52-64.

Puspitawati, H. (2012). Gender dan Keluarga [Gender and Family]. Bogor, Indonesia: IPB Press.

Robila, M. (2006). Economic pressure and social exclusion in Europe. The Social Science Journal, 43, 85-97. doi: 10.1016/j.soscij.2005.12.009.

Rosidah, U., Hartoyo, \& Muflikhati, I. (2012). Kajian Strategi Kopingdan Perilaku Investasi Anak Pada Keluarga Buruh Pemetik Melati Gambir. [Study on family coping strategy and investment behavior on children of jasmine officinale labor families]. Jurnal Ilmu Keluarga dan Konsumen, 5(1).

Son, H. H. (2008). Conditional cash transfer programs: An effective tool for poverty alleviation? (Economics and Research Department Policy Brief Series No. 51). Retrieved from http://www.adb.org/sites/default/files/publication/28104/pb051.pdf.

Statistics Indonesia. (2012). Official Statistics News. Retrieved from http:// www.bps.go.id/?news=981. 
Statistics Indonesia. (2016). Number of Poor People by Province, 2013-2015. Jakarta, Indonesia: Author.

United Nations Development Program. Human Development Index trends, 1980-2012. Retrieved from http://hdr.undp.org/hdr4press/press/outreach/figures/HDI_ Trends_2013.pdf.

Voydanoff, P., \& Donnelly, B. W. (1988). Economic distress, family coping, and quality of family life. In P. Voydanoff, \& L. C. Majka (Eds.), Families and economic distress: Coping strategies and social policy (pp. 97-117). Newbury Park, CA: Sage.

Zepeda, E. (2006). Do CCTs reduce poverty? (IPC One Pager No. 21). Retrieved from http://www.ipc-undp.org/pub/ IPCOnePager21.pdf. 